\title{
Analisis Yuridis Pemutusan Hubungan Kerja Akibat Kesalahan Berat Pekerja
}

\author{
Sonhaji \\ Fakultas Hukum, Universitas Diponegoro \\ E-mail : sonhajimuh19@gmail.com
}

\begin{abstract}
The result of this research shows that the case of serious mistake did by worker/laborer in Thailindo Bara Pratama Corporation has gone through bipartite, mediation and conciliation processes. However all three of them did not reach agreement and Thailindo Bara Pratama Corporation filed a lawsuit against the worker/laborer to the Industrial Relations Court. Palangkaraya Industrial Relations Court's Verdict Number 04/G/2012/PHI.PN.PL.R decides that the workers have committed a serious mistake and is subjected to termination of employment but the employer still has to pay their deferred obligation to the worker/laborer. Despite the termination of the employment due to the serious mistake requested by the employer to the Industrial Relations Court is granted, but within the verdict there are still many legal loopholes.
\end{abstract}

Keywords : Employment, Laborer Serious Mistake, PT. Thailindo Bara Pratama

\begin{abstract}
Abstrak
Dari hasil penelitian dapat diketahui bahwa kasus mengenai kesalahan berat pekerja/buruh di PT. Thailindo Bara Pratama telah melalui proses bipartit, mediasi dan konsiliasi. Namun ketiganya tidak mencapai kesepakatan dan PT. Thailindo Bara Pratama mengajukan gugatan ke Pengadilan Hubungan Industrial. Putusan Pengadilan Hubungan Industrial Palangkaraya Nomor 04/G/2012/PHI.PN.PL.R menyatakan bahwa pekerja/buruh telah melakukan kesalahan berat dan dijatuhi pemutusan hubungan kerja namun pengusaha tetap harus membayarkan kewajibannya yang tertunda terhadap pekerja/buruh. Meskipun pemutusan hubungan kerja akibat kesalahan berat yang dimintakan penetapannya oleh pengusaha kepada Pengadilan Hubungan Industrial dikabulkan, namun di dalam putusan pengadilan tersebut masih terdapat banyak celah hukum.
\end{abstract}

Kata kunci : Hubungan Kerja, Kesalahan Berat Pekerja PT. Thailindo Bara Pratama 


\section{A. Pendahuluan}

Hubungan kerja antara pekerja/buruh dengan perusahaan ditandai dengan ditandatanganinya Surat Perjanjian Kerja oleh kedua belah pihak. ${ }^{1}$ Permasalahan antara pengusaha dan pekerja mungkin bisa terjadi di dalam hubungan kerja tersebut, baik sederhana maupun kompleks, baik yang dapat diselesaikan secara kekeluargaan maupun yang harus diselesaikan melalui jalur hukum. Terkait dalam hal tersebut, pemutusan hubungan kerja adalah salah satunya.

Menurut Tulus ${ }^{2}$, pemutusan hubungan kerja (separation) adalah mengembalikan karyawan ke masyarakat. Sedangkan menurut Hasibuan pemutusan hubungan kerja adalah pemberhentian seseorang karyawan dengan suatu organisasi (perusahaan). Pemutusan hubungan kerja adalah permasalahan utama dalam hubungan antara pengusaha dan pekerja di samping permasalahan upah. Pemutusan hubungan kerja pada hakikatnya merupakan suatu pengakhiran sumber nafkah bagi pekerja/buruh dan keluarganya yang dilakukan oleh pengusaha. Pemutusan hubungan kerja merupakan awal hilangnya mata pencaharian bagi pekerja/buruh yang juga menyebabkan kehilangan pekerjaan dan penghasilan. Oleh sebab itu, istilah pemutusan hubungan kerja bisa menjadi momok bagi setiap pekerja/buruh karena mereka dan keluarganya terancam kelangsungan hidupnya dan merasakan derita akibat dari pemutusan bubungan kerja itu. Mengingat fakta di lapangan bahwa mencari pekerjaan tidaklah mudah seperti yang dibayangkan. Semakin ketatnya persaingan, angkatan kerja terus bertambah dan kondisi dunia usaha yang selalu fluktuatif, sangatlah wajar jika pekerja/buruh selalu khawatir dengan ancaman pemutusan hubungan kerja tersebut. ${ }^{3}$

Umar Kasim mengemukakan bahwa berakhirnya hubungan kerja dapat mengakibatkan pekerja/buruh kehilangan mata pencaharian yang berarti pula permulaan masa pengangguran dengan segala akibatnya, sehingga untuk menjamin kepastian hidup pekerja/buruh, seharusnya tidak ada pemutusan hubungan kerja.

\footnotetext{
1 Suhartoyo, Jurnal Masalah-Masalah Hukum:Perlindungan Hukum Terhadap Pekerja/Buruh Penyandang Disabilitas di Indonesia, (Semarang : Fakultas Hukum Diponegoro, 2014), hlm. 477

2 Brankas Everest, Pemutusan Hubungan https://brankaseverest.wordpress.com/artikel/pemutusan-hubungan-kerja/ diakses tanggal 5 Desember 2017, pukul 15.12 WIB

3 Abdul Khakim, Dasar-Dasar Hukum Ketenagakerjaan Indonesia, Citra Aditya Bakti, Bandung, 2014, hlm. 175
} 
Kenyataan membuktikan bahwa pemutusan hubungan kerja tidak dapat dicegah seluruhnya. Umar Kasim juga mengemukakan bahwa pemutusan hubungan kerja merupakan isu yang sensitif, pengusaha seharusnya bijaksana dalam melakukan pemutusan hubungan kerja karena pemutusan hubungan kerja dapat menurunkan kesejahteraan masyarakat, meningkatkan peluang kehilangan pekerjaan dan mengakibatkan pengangguran. Bagi pengusaha dan perusahaan terjadinya pemutusan hubungan kerja sebenarnya merupakan suatu kerugian karena harus melepas pekerja/buruh yang selama ini sadar sudah dilatih dengan mengeluarkan ongkos yang banyak dan sudah mengetahui cara kerja yang dibutuhkan perusahaan tetapi ada beberapa saat perlu dilakukan pemutusan hubungan kerja untuk menyelamatkan perusahaan serta untuk mencegah korban yang lebih besar. ${ }^{4}$ Hubungan antara pengusaha dengan pekerja/buruh akan tetap berlangsung dengan baik apabila kedua belah pihak yang saling membutuhkan tersebut dapat saling menjaga keharmonisan. Pemutusan hubungan kerja dapat dihindari jika pengusaha dan pekerja/buruh tidak melanggar berbagai ketentuan yang telah diatur dalam Undang-Undang Nomor 13 Tahun 2003 tentang Ketenagakerjaan beserta peraturan pelaksanaannya, Perjanjian Kerja, Peraturan Perusahaan, dan Perjanjian Kerja Bersama yang menjadi dasar pengusaha dan pekerja/buruh dalam menjalankan hubungan kerja yang melindungi hak dan kewajiban kedua belah pihak. Kesalahan atau pelanggaran yang mungkin dilakukan oleh salah satu pihak, pengusaha atau pekerja/buruh, sudah ditentukan sanksinya sesuai dengan Undang-Undang Nomor 13 Tahun 2003 tentang Ketenagakerjaan beserta peraturan pelaksanaannya, Perjanjian Kerja, Peraturan Perusahaan, dan Perjanjian Kerja Bersama. Sanksi pelanggaran bagi pekerja/buruh yang paling berat dalam hubungan kerja adalah pemutusan hubungan kerja itu sendiri yang mengakibatkan berakhirnya hak dan kewajiban antara pengusaha dan pekerja/buruh. Pekerja/buruh yang bekerja pada pihak lain dalam hal ini pengusaha berada di bawah pimpinan pengusaha maka kewajiban terpenting bagi pekerja/buruh adalah melakukan pekerjaan menurut petunjuk pengusaha.

${ }^{4}$ Broto Suwiryo, Hukum Ketenagakerjaan, LaksBang PRESSindo, Yogyakarta, hlm. 97 
Kewajiban pekerja/buruh pada umumnya terlihat pada hak pengusaha, seperti juga hak pekerja/buruh terlihat pada kewajiban pengusaha. Pemutusan hubungan kerja yang terjadi setelah adanya hubungan kerja dan perjanjian kerja berarti hak pekerja/buruh harus dipenuhi oleh pengusaha sesuai dengan aturan dalam perjanjian yang telah disetujui bersama.

Pekerja/buruh yang baik adalah pekerja/buruh yang melaksanakan kewajibannya dengan baik seperti yang tercantum dalam Pasal 1603 Kitab Undang-Undang Hukum Perdata yang meliputi antara lain kewajiban buruh melakukan pekerjaan menurut kemampuannya yang sebaik-baiknya, kewajiban untuk tidak mewakilkan pekerjaannya kepada pihak ketiga tanpa seizin pengusaha serta menaati aturan-aturan tentang melakukan pekerjaan dan tata tertib. Kesalahan yang dilakukan oleh pekerja/buruh pada umumnya dapat digolongkan menjadi dua yaitu kesalahan ringan dan kesalahan berat. Kesalahan ringan diusahakan untuk diselesaikan secara kekeluargaan dan dengan teguran lisan dan/atau tertulis. Kesalahan berat adalah di mana bagi perusahaan dan pengusaha merasa sangat dirugikan dan kerugian dinilai cukup besar oleh pengusaha dan menghambat kelangsungan perusahaan.

Sikap dan perilaku pekerja/buruh mempengaruhi kualifikasinya dalam bekerja dan hal itu merupakan kewenangan pengusaha, salah satunya mengenai disiplin kerja. Disiplin kerja dapat disimpulkan sebagai kesadaran dan kesediaan seseorang menaati semua peraturan perusahaan dan norma-norma sosial yang berlaku serta menunjukkan suatu kondisi atau sikap hormat yang ada pada diri pekerja/buruh terhadap peraturan dan ketetapan perusahaan. Bagi pengusaha, adanya disiplin kerja akan menjamin terpeliharanya tata tertib dan kelancaran pelaksanaan tugas sehingga diperoleh hasil yang optimal. Bagi pekerja/buruh disiplin kerja akan menciptakan suasana kerja yang menyenangkan dan semangat kerja karyawan juga bertambah. Hal ini membuat pekerja/buruh dapat melaksanakan pekerjaannya dengan penuh kesadaran. Disiplin kerja tidak menghilangkan adanya rasa kurang puas dari pengusaha karena menurut Zeni Asyhadie pokok pangkal rasa kurang puas pengusaha terhadap pekerja/buruh meliputi perilaku penugasan yang kurang sesuai dengan kepribadian, daya kerja dan 
kemampuan kerja yang kurang sesuai dengan pekerjaan serta masalah pribadi antara pengusaha dengan pekerja/buruh. ${ }^{5}$

Pengusaha, dalam kasus ini yaitu PT. Thailindo Bara Pratama melalui tim penilai menyatakan bahwa tindakan salah satu pekerja/buruhnya kurang atau bahkan tidak sesuai dengan yang diharapkan dan digolongkan ke dalam kesalahan berat. Kesalahan berat pada umumnya adalah ketidakjujuran, dijatuhi hukuman penjara oleh pengadilan yang sudah memiliki kekuatan hukum tetap, perilaku negatif yang sangat merusak citra perusahaan, dan sikap, ucapan, dan tindakan yang mengakibatkan keberadaannya dalam perusahaan tidak lagi diinginkan. PT. Thailindo Bara Pratama sebagai pengusaha pihak pemberi kerja langsung menjatuhkan pemutusan hubungan kerja tanpa penyelesaian pemenuhan hak pekerja/buruh untuk menghindari kerugian yang lebih besar.

Menurut Charles D. Drake pelanggaran dalam hubungan kerja disebabkan oleh perbedaan paham dalam pelaksanaan hukum ketenagakerjaan ${ }^{6}$. Perbedaan paham terlihat melalui cara pandang hakim dan pengusaha sehingga walaupun pada akhirnya memenangkan perkara, pengusaha tetap dinyatakan bersalah oleh hakim. Pengusaha dan pekerja/buruh harus mengusahakan segala upaya agar tidak terjadi pemutusan hubungan kerja. Segala upaya berarti bahwa kegiatan-kegiatan yang positif seperti perbaikan metode kerja dan pembinaan kepada pekerja/buruh. Bila segala upaya telah dilakukan namun tidak mencapai kesepakatan antara pengusaha dan pekerja/buruh baru dapat dilakukan pemutusan hubungan kerja. Menurut Samsuddin pemutusan hubungan kerja merupakan hal yang wajar dalam dunia ketenagakerjaan, tetapi pelaksanaannya membutuhkan waktu, biaya, dan tenaga atau pikiran sehingga pemutusan hubungan kerja harus merupakan upaya terakhir yang dilakukan ${ }^{7}$. Pengusaha, pekerja/buruh dan pihak-pihak terkait harus mengusahakan agar tidak terjadi pemutusan hubungan kerja.

\footnotetext{
${ }^{5}$ R. Bambang Joni, Hukum Ketenagakerjaan, Pustaka Setia, Bandung, 2015, hlm. 289

${ }^{6}$ Loc.cit, hlm 290

${ }^{7}$ Iron Sarira. PHK Dengan Alasan Kesalahan Berat. http://business- $\quad$ law.binus.ac.id/2016/04/30/phkdengan-alasan-kesalahan-berat/ diakses tanggal 5 Desember 2017 pukul 15.01
} 
Kasus ini menunjukkan beberapa celah hukum yaitu proses bipartit dan tripartit yang gagal karena PT. Thailindo Bara Pratama sebagai penggugat tidak melampirkan risalah mediasi, perbedaan pemahaman dan dasar hukum pemutusan hubungan kerja akibat kesalahan berat pekerja/buruh antara pengusaha dengan Pengadilan Hubungan Industrial Palangkaraya, tidak ada penetapan mengenai kecelakaan lalu lintas oleh pihak yang berwenang dan peraturan perusahaan yang bertentangan dengan peraturan perundang-undangan. Dari uraian tersebut, permasalahan yang dapat disusun adalah sebagai berikut : Apa sajakah peraturan perundang-undangan yang mendasari pemutusan hubungan kerja akibat kesalahan berat pekerja/buruh? Bagaimanakah mekanisme pemutusan hubungan kerja akibat kesalahan berat pekerja/buruh? Bagaimanakah putusan hakim di dalam kasus PT. Thailindo Bara Pratama.

\section{Metode Penelitian}

Metode pendekatan yang digunakan dalam penelitian ini adalah yuridis normatif. Sesuai dengan pengertiannya menurut Peter Mahmud Makzuki bahwa penelitian normatif adalah suatu proses untuk menemukan suatu aturan hukum, prinsip hukum, maupun doktrin hukum untuk permasalahan hukum yang dihadapi. Penelitian nomatif dilakukan untuk menghasilkan argumentasi, teori atau konsep baru sebagai prepenelitian dalam menyelesaikan permasalahan yang dihadapi ${ }^{8}$. Pendekatan yuridis normatif adalah pendekatan yang dilakukan berdasarkan bahan hukum utama dengan cara menganalisis teori-teori, konsep-konsep, asas-asas hukum serta peraturan perundang-undangan yang berhubungan dengan penelitian ini. Dr. Johnny Ibrahim menyatakan bahwa sebagai ilmu praktis normologis, ilmu hukum normatif berhubungan langsung dengan praktik hukum yang menyangkut dua aspek utama yaitu tentang pembentukan hukum dan tentang penerapan hukum ${ }^{9}$. Data yang diguakan dalam penelitian ini adalah data sekunder yang diperoleh melalui peraturan perundang-undangan yang berlaku, jurnal, buku literatur dan putusan pengadilan.

\footnotetext{
${ }^{8}$ Purwanti, Ani (2017), Metode Penelitian dan Penelitian, Materi Kuliah:Metode Penelitian dan Penelitian, Universitas Diponegoro, Semarang

${ }^{9}$ Hardijan Rusli, "Metode Penelitian Hukum Normatif: Bagaimana?", Law Review Fakultas Hukum Universitas Pelita Harapan, Volume V No. 3 Tahun 2006, hlm. 50
} 
Spesifikasi pada penelitian ini adalah deskriptif analitis. Deskriptif berarti menggambarkan apa adanya dan analitis berarti logis, mendalam dan sistematis. Metode deskriptif analitis memusatkan perhatian kepada masalah-masalah sebagaimana adanya pada saat penelitian dilaksanakan, hasil penelitian kemudian diolah dan dianalisis untuk diambil kesimpulannya.

Analisis data dalam penelitian ini dilakukan secara kualitatif dan deskriptif analitis. Kualitatif karena data-data yang diperoleh dalam penelitian penelitian ini sukar diukur secara pasti melalui angka-angka maka data-data yang diperoleh tersebut akan dijelaskan dan dianalisis dengan kata-kata dan kalimat-kalimat. Teknik analisis data secara kualitatif mendasarkan pada berbagai tulisan yang berkaitan dengan peraturan perundang-undangan yang digunakan sebagai landasan maupun pendapat ahli sebagai bagan perbandingan teori dan kenyataan dalam praktik sehingga akan dihasilkan data yang benar-benar menggambarkan permasalahan. Deskriptif analitis karena data-data yang diperoleh dalam penelitian penelitian ini akan dijelaskan dan dianalisis ke dalam bentuk laporan tertulis secara logis dan sistematis hingga mendapatkan kesimpulan.

\section{B. Pembahasan}

\section{Gambaran Umum Kasus PT. Thailindo Bara Pratama Berdasarkan Putusan Pengadilan Hubungan Industrial Palangkaraya No.04/G/2012/PHI.PN.PL.R}

Pada hari Sabtu tanggal 12 November 2011 sekitar pukul 15.30 WIB, tergugat berada dalam perjalanan pulang ke rumah dari base camp dengan mengemudikan mobil inventaris penggugat jenis Hilux dengan nomor lambung PT. 25. Di dalam perjalanan, mobil inventaris penggugat yang dikemudikan tergugat tersebut berpapasan dengan 1 (satu) unit mobil PS di jalan aspal yang rusak tepatnya di Desa Ugang Sayu kilometer 21. Akibat dari papasan itu tergugat tidak dapat mengendalikan mobil hingga terguling ke kanan mengakibatkan ban depan kanan dan cabin pecah. Perusahaan berdasarkan ketentuan dan peraturan keselamatan kerja memerintahkan Tim Safety Committee untuk melakukan investigasi sesuai Standard Operational Procedure (SOP). Hasil investigasi dari Tim Safety Committee menyimpulkan bahwa 
telah terdapat fakta hukum yaitu tergugat telah secara kurang hati-hati/ceroboh/lalai mengemudikan mobil inventaris penggugat tersebut. Penggugat juga telah menilai tergugat melanggar Keputusan Menteri Tenaga Kerja Nomor 555.K/26/M.PE/1995. Kerugian material yang ditimbulkan dari kecelakaan tersebut adalah sebesar Rp 173.500.000,00 (seratus tujuh puluh tiga juta lima ratus ribu rupiah). Kerugian tersebut membuat tindakan yang dilakukan tergugat termasuk ke dalam kesalahan berat sesuai Pasal 40 Peraturan Perusahaan juncto Keputusan Menteri Tenaga Kerja dan Transmigrasi Republik Indonesia Nomor 150/KEP-MEN/2000. Karena sudah ada Peraturan Perusahaan yang mengatur mengenai kesalahan berat maka penyelesaian tunduk dan mengacu kepada Peraturan Perusahaan.

Dalam penyelesaian perselisihan ini telah terlebih dahulu dilakukan upaya bipartit antara kedua belah pihak. Namun upaya bipartit gagal mencapai kesepakatan maka penggugat langsung mengajukan pendaftaran dan permohonan pemutusan hubungan kerja atas diri tergugat ke Dinas Tenaga Kerja dan Transmigrasi Kabupaten Barito Selatan pada 13 Desember 2011 untuk dilakukan upaya tripartit melalui mediasi. Upaya mediasi dilakukan oleh kedua belah pihak dan Kepala Dinas Tenaga Kerja dan Transmigrasi Kabupaten Barito Selatan sebagai mediator juga gagal sehingga mediator mengeluarkan anjuran. Namun anjuran itu ditolak oleh penggugat. Demi kepastian hukum, penggugat mendaftarkan gugatan pemutusan hubungan kerja terhadap penggugat ke Pengadilan Hubungan Industrial Palangkaraya.

Upaya bipartit dan tripartit tidak menghasilkan kesepakatan karena tergugat menolak keputusan pemutusan hubungan kerja oleh penggugat. Penolakan dari tergugat membuat penggugat melakukan skorsing atas dirinya sejak 13 Desember 2011 dengan tetap memberikan gaji pokok. Di dalam persidangan ditemukan fakta bahwa ternyata selama masa skorsing pemberian gaji terhadap tergugat ditunda oleh penggugat. Penggugat memohon kepada majelis hakim untuk menerima dan mengabulkan gugatannya seluruhnya serta menyatakan pemutusan hubungan kerja atas diri tergugat akibat kesalahan berat sejak putusan pengadilan. Penggugat juga memohon untuk hanya memberikan kepada tergugat uang penggantian hak saja 
sebesar Rp 3.366.000,00 (tiga juta tiga ratus enam puluh enam ribu rupiah) dan membebankan biaya perkara menurut hukum.

Atas gugatan penggugat, tergugat melakukan jawaban. Dalam jawabannya, tergugat menyatakan bahwa gugatan adalah tidak sah karena tidak memenuhi syarat formil sebab penggugat tidak menyertakan risalah penyelesaian mediasi sehingga mejelis hakim seharusnya mengembalikan gugatan tersebut kapada penggugat. Tergugat juga memberikan jawaban bahwa berdasarkan Putusan Mahkamah Konstitusi Nomor 012/PPU-01/2003, Pasal 158 Undang-Undang Nomor 13 Tahun 2003 dinyatakan tidak mempunyai kekuatan hukum mengikat sehingga pekerja/buruh yang melakukan kesalahan berat hanya dapat dijatuhi pemutusan hubungan kerja setelah ada putusan pidana yang berkekuatan hukum tetap. Tergugat mengakui ada kesalahan yang dilakukannya namun merupakan kesalahan ringan.

Tergugat menggugat balik penggugat untuk akomodasi, meliputi biaya sewa rumah dan uang makan selama 2 tahun dari tahun 2009 sampai 2011 sebesar Rp 9.600.000,00 (sembilan juta enam ratus ribu rupiah,) untuk penggantian uang sewa rumah dan $\mathrm{Rp}$ 7.200.000,00 (tujuh juta dua ratus ribu rupiah), untuk penggantian uang makan, perumahan khusus karyawan dan penggugat merasa ada diskriminasi terhadap pekerja lokal dan keterlambatan pembayaran upah dan meminta kompensasi atas keterlambatan tersebut. Tergugat meminta pesangon sebesar Rp 15.180.000,00 (lima belas juta seratus delapan puluh ribu rupiah) dan uang penggantian hak sebesar Rp 3.360.000,00 (tiga juta tiga ratus enam puluh ribu rupiah). Atas jawaban tergugat, penggugat tidak mengajukan replik sehingga tergugat tidak mengajukan duplik.

Tahap bipartit dan tripartit adalah benar sudah dilakukan namun penggugat tidak melampirkan risalah ke duanya sama sekali, karena tidak ada bukti lampirannya di dalam putusan pengadilan namun telah dilampirkan oleh tergugat beberapa surat panggilan untuk penyelesaian perselisihan, risalah dan anjuran. Di dalam persidangan penggugat tidak dapat menunjukkan bukti asli surat skorsing, surat pembayaran gaji selama skorsing dan foto kerusakan unit. Empat orang saksi dipanggil ke persidangan untuk memberikan keterangannya, tiga orang dari pihak penggugat dan satu orang dari 
pihak tergugat. Tergugat melalui kuasanya mengajukan kesimpulan pada 26 Maret 2012.

Putusan yang dijatuhkan pada tanggal 3 April 2012 oleh majelis hakim yang beranggotakan Hadi Masruri, S.H., MHum sebagai ketua majelis, Syamsul Kamar, S.H. sebagai hakim anggota dan Teki Prasedyanti, S.H. sebagai hakim anggota serta sebagai panitera pengganti adalah Partono, S.H. menyatakan bahwa tergugat sudah melakukan kesalahan berat maka pemutusan hubungan kerja dinyatakan sah, namun penggugat tetap harus membayarkan kewajibannya yang tertunda kepada tergugat berupa empat kali gaji selama empat bulan skorsing sebesar Rp 8.800.000,00 serta uang penggantian hak sebesar Rp 3.360.000,00.

\section{Peraturan Perundang-undangan yang Mendasari Pemutusan Hubungan}

\section{Kerja Akibat Kesalahan Berat Pekerja}

1. Undang-Undang Nomor 13 Tahun 2003 tentang Ketenagakerjaan Pasal 158

2. Undang-Undang Nomor 2 Tahun 2004 tentang Penyelesaian Perselisihan Hubungan Industrial yang menjadi dasar hukum mekanisme pemutusan hubungan kerja baik secara umum maupun akibat kesalahan berat pekerja yaitu yaitu melalui proses bipartit, tripartit dan Pengadilan Hubungan Industrial

3. Putusan Mahkamah Konstitusi Republik Indonesia Nomor 12/PUU-I/2003

4. Surat Edaran Menteri Tenaga Kerja dan Transmigrasi Nomor SE.13/MEN/SJHKI/I/2005

Penjelasannya adalah sebagai berikut :

Belum ada definisi yang pasti tentang kesalahan berat walaupun Pasal 158 ayat (1) Undang-Undang Nomor 13 Tahun 2003 tentang Ketenagakerjaan pada huruf a sampai $\mathrm{j}$ telah menerangkan jenis-jenis kesalahan berat yang dapat mengakibatkan pemutusan hubungan kerja dan apa yang harus dilakukan oleh pengusaha saat kesalahan itu dilakukan oleh pekerja/buruh. Kesalahan itu meliputi pekerja/buruh melakukan penipuan, pencurian, atau pengggelapan barang dan/atau uang milik perusahaan; atau pekerja/buruh memberikan keterangan palsu atau yang dipalsukan sehingga merugikan perusahaan; atau mabuk, meminum minuman keras; atau melakukan perbuatan asusila atau perjudian di lingkungan kerja; atau menyerang, 
menganiaya, mengancam, atau mengintimidasi teman sekerja atau pengusaha di lingkungan kerja; dan seterusnya. Kesalahan berat itu harus didukung dengan bukti, yakni pekerja/buruh tertangkap tangan, atau ada pengakuan dari pekerja/buruh yang bersangkutan, atau bukti lain berupa laporan kejadian yang dibuat oleh pihak yang berwenang di perusahaan yang bersangkutan dan didukung oleh sekurang-kurangnya dua alat bukti atau saksi.

Pengusaha dapat melakukan pemutusan hubungan kerja namun Pasal 155 juncto Pasal 151 Undang-Undang Nomor 13 Tahun 2003 tentang Ketenagakerjaan melarang pemutusan hubungan kerja tanpa adanya penetapan dari lembaga penyelesaian perselisihan hubungan industrial. Pemutusan hubungan kerja tanpa penetapan tersebut adalah batal demi hukum. Pasal 155 ayat (3) Undang-Undang Nomor 13 Tahun 2003 tentang Ketenagakerjaan memungkinkan pengecualian bahwa sebelum ada penetapan pelaku usaha boleh menjatuhkan skorsing dengan tetap membayar upah beserta hak-hak lainnya yang biasa diterima pekerja/buruh tersebut. Pasal 155 juncto Pasal 151 ini bertolak belakang dengan Pasal 158 karena membuka kesempatan pemutusan hubungan kerja oleh pengusaha apabila pekerja/buruh melakukan kesalahan berat. Kerancuan Pasal 158 ini mendorong dilakukannya uji materiil Undang-Undang Ketenagakerjaan terhadap Undang-Undang Dasar Negara Republik Indonesia Tahun 1945.

Mahkamah Konstitusi pada tanggal 28 Oktober 2004 telah mengeluarkan putusan dengan Nomor 12/PUU-I/2003 yang dalam salah satu pertimbangannya menyatakan bahwa kesalahan berat yang diatur dalam Pasal 158 adalah perbuatan pidana yang telah diatur dalam Kitab Undang-Undang Hukum Pidana. Ketentuan pasal ini dinilai telah melanggar asas praduga tak bersalah karena Pasal telah memberikan dasar bagi pengusaha untuk melakukan pemutusan hubungan kerja secara sepihak sebelum ada putusan pengadilan. Putusan Mahkamah Konstitusi tersebut menerangkan bahwa pemutusan hubungan kerja akibat kesalahan berat baru dapat dilakukan oleh pengusaha setelah pelaku terbukti dan dinyatakan bersalah oleh pengadilan. 
Sebagai tindak lanjut, pada tanggal 7 Januari 2005, Menteri Tenaga Kerja dan Transmigrasi (Menakertrans) mengeluarkan Surat Edaran No. SE.13/MEN/SJHKI/I/2005 yang meminta pengusaha melakukan pemutusan hubungan kerja terhadap pekerja/buruh karena alasan kesalahan berat setelah adanya putusan pengadilan yang berkekuatan hukum tetap yang menyatakan bahwa pekerja/buruh benar telah melakukan kesalahan berat.

Pasal 158 ayat (3) Undang-Undang Nomor 13 Tahun 2003 tentang Ketenagakerjaan mengatur bahwa pekerja/buruh yang terbukti melakukan kesalahan berat tetap berhak mendapatkan uang penggantian hak sebagaimana yang tercantum dalam Pasal 156 Undang-Undang Nomor 13 tahun 2003 tentang Ketenagakerjaan, didukung pula dengan Keputusan Menteri Tenaga Kerja dan Transmigrasi Nomor KEP-150/MEN/2000 mengatur bahwa pekerja/buruh yang dikenai pemutusan hubungan kerja tetap berhak atas uang ganti kerugan dan uang jasa tanpa mendapat uang pesangon. Hal ini menyebabkan PT. Thailindo Bara Pratama dinilai melanggar hukum oleh Pengadilan Hubungan Industrial Palangkaraya.

Pasal 171 juncto Pasal 158 ayat (1) Undang-Undang Nomor 13 Tahun 2003 tentang Ketenagakerjaan mengatur bahwa pemutusan hubungan kerja akibat kesalahan berat pekerja/buruh tidak perlu penetapan dari lembaga Penyelesaian Perselisihan Hubungan Industrial tetapi Pasal 158 Undang-Undang Nomor 13 Tahun 2003 Tentang Ketenagakerjaan telah melalui uji materiil dan menghasilkan putusan Mahkamah Konsitusi No. 012/PUU-I/2003 menghasilkan amar putusan yang pada pokoknya menyatakan ketentuan Pasal 158 Undang-Undang Nomor 13 Tahun 2003 tentang Ketenagakerjaan bertentangan dengan Undang-Undang Dasar Negara Republik Indonesia tahun 1945 dan tidak mempunyai kekuatan hukum yang mengikat. Surat Edaran Kementerian Tenaga Kerja dan Transmigrasi Nomor: SE.13/MEN/SJ-HK/I/2005 pada pokoknya mengatur dua hal, salah satunya Pemutusan Hubungan kerja dapat dilakukan setelah ada putusan pidana yang mempunyai kekuatan hukum tetap. Pencabutan Pasal 158 Undang-Undang Nomor 13 Tahun 2003 tentang Ketenagakerjaan membuat rincian kesalahan berat oleh pekerja/buruh dalam rangka suatu hubungan kerja menjadi pengaturan di luar 
Undang-Undang Nomor 13 Tahun 2003 tentang Ketenagakerjaan. Kesalahan berat sepenuhnya berada dalam putusan pengadilan. Kesalahan berat adalah perbuatan yang pada umumnya merupakan tindak pidana yang terbukti dilakukan dan dihukum oleh pengadilan berdasarkan putusan yang telah berkekuatan hukum tetap. Sepanjang putusan itu belum dinyatakan oleh hakim maka pemutusan hubungan kerja belum dapat dijatuhkan kecuali berformat skorsing.

Peraturan perusahaan PT. Thailindo Bara Pratama mengenai pemutusan hubungan kerja akibat kesalahan berat pekerja/buruh bertentangan dengan Putusan Mahkamah Konstitusi dan Surat Edaran Menteri Tenaga Kerja dan Transmigrasi maka seharusnya seperti yang tertuang dalam Pasal 52 ayat (3) Undang-Undang Nomor 13 Tahun 2003 tentang Ketenagakerjaan yang mengatur bahwa Pertaturan Perusahaan, Perjanjian Kerja dan Perjanjian Kerja Bersama yang tidak sesuai dengan peraturan perundang-undangan di adalah batal demi hukum, apabila di dalam Peraturan Perusahaan PT Thailindo Bara Pratama dinyatakan pemutusan hubungan kerja akibat kesalahan berat dapat dilakukan tanpa harus berdasarkan putusan pengadilan yang berkekuatan hukum tetap, Peraturan Perusahaan tersebut batal demi hukum.

Kasus pemutusan hubungan kerja seperti dalam kasus PT. Thailindo Bara Pratama ini menurut jenis-jenis pemutusan hubungan kerja oleh Manulang merupakan jenis pemutusan hubungan kerja dismissal yaitu putusnya hubungan kerja karena karyawan melakukan tindakan pelanggaran disiplin yang telah ditetapkan. Sedangkan menurut jenis-jenis pemutusan hubungan kerja oleh Filippo merupakan jenis pemutusan hubungan kerja discharge yaitu pemutusan hubungan kerja berdasarkan kenyataan bahwa karyawan kurang mempunyai sikap dan perilaku kerja yang memuaskan. ${ }^{10}$

Kasus PT. Thailindo Bara Pratama diselesaikan melalui jalur hukum dengan Nomor Putusan Pengadilan Hubungan Industrial Palangkaraya Nomor 04/G/2012/PHI.PN.PL.R. Putusan Pengadilan Hubungan Industrial Palangkaraya

\footnotetext{
${ }^{10}$ Sri Zulhartati, "Pengaruh Pemutusan Hubungan Kerja Terhadap Karyawan Perusahaan”, (Jurnal Pendidikan IPS, FKIP, Universitas Tanjungpura Pontianak, 2012), hlm. 82
} 
tersebut memberi penjelasan bahwa kelalaian yang dilakukan oleh pekerja/buruh tersebut tergolong ke dalam kesalahan berat dan pengusaha dinilai melakukan pelanggaran hukum karena memutus hubungan kerja akibat kesalahan berat di luar putusan pengadilan dan tidak memenuhi hak pekerja/buruh serta tidak menyertakan risalah mediasai kedua belah pihak.

\section{Analisis Putusan Pengadilan Hubungan Industrial Palangkaraya No.04/G/2012/PHI.PN.PL.R}

Hasil analisis putusan hakim di dalam kasus PT. Thailindo Bara Pratama adalah sebagai berikut :

1. Perselisihan antara penggugat dan penggugat adalah benar perselisihan pemutusan hubungan kerja karena terjadi antara pengusaha dengan pekerja/buruh disebabkan oleh pekerja yang tidak menerima pemutusan hubungan kerja oleh pengusaha

2. Hakim keliru menerapkan hukum di dalam putusan kasus di PT. Thailindo Bara Pratama karena tidak mendasarkan pada putusan pengadilan pidana berkekuatan hukum tetap yang menyatakan bahwa tergugat bersalah

3. Kesalahan berat yang dimaksud oleh PT. Thailindo Bara Pratama atas perbuatan tergugat tidak sesuai dengan kriteria di dalam Pasal 158 Undang-Undang Nomor 13 Tahun 2003 tentang Ketenagakerjaan

1. Terdapat perbedaan pengertian kesalahan berat antara pengusaha yang dituangkan ke dalam peraturan perusahaan dengan apa yang tertuang di dalam Pasal 158 Undang-Undang Nomor 13 Tahun 2003 tentang Ketenagakerjaan, sehingga pengusaha langsung menjatuhkan pemutusan hubungan kerja tanpa melihat telah dikeluarkan Putusan Mahkamah Konstitusi yang menyatakan bahwa pemutusan kesalahan kerja akibat kesalahan berat pekerja harus berdasarkan keputusan pengadilan yang berkekuatan hukum tetap

2. Dari pernyataan ketiga saksi dari pihak penggugat terlihat bahwa berita pemutusan hubungan kerja atas diri Lundi sudah tersebar dan diketahui, padahal menurut bukti di persidangan sebenarnya Lundi sedang dalam masa skorsing 
3. Dari putusan majelis hakim, terlihat bahwa majelis hakim lebih melihat keterangan dari penggugat

4. Mengenai Keputusan Menteri Tenaga Kerja Nomor 555 Tahun 1995 yaitu tentang Keselamatan dan Kesehatan Kerja Pertambangan Umum di dalam proses persidangan hingga putusan tidak dijelaskan bagaian mana dari keputusan tersebut yang dilanggar oleh tergugat

5. Mengenai Keputusan Menteri Tenaga Kerja Nomor 150 Tahun 2000 yang menjadi dasar Peraturan Perusahaan PT. Thailindo Bara Pratama yaitu adalah huruf $\mathrm{k}$ yang mengatur mengenai ;ain-lain dalam peraturan perusahaan dan perjanjian kerja

6. Berita mengenai kecelakaan yang dialami tergugat apabila melihat dari keterangan saksi sudah tersebar di lingkungan kerja, bahkan ketiga saksi dari pihak penggugat menyatakan yang mereka ketahui adalah bahwa tergugat sudah dijatuhi pemutusan hubungan kerja. Padahal sebenarnya masih dalam masa skorsing. Hal ini sangat tidak baik bagi kerharmonisan antar pekerja/buruh dan antar pengusaha dengan buruh di lingkungan kerja

7. Penggugat tidak memberikan tergugat surat peringatan terlebih dahulu, maka hal ini bertentangan dengan Pasal 161 Undang-Undang Nomor 13 Tahun 2003 tentang Ketenagakerjaan

Putusan hakim di dalam kasus PT. Thailindo Bara Pratama terdapat beberapa hambatan antara lain :

1. Tidak terdapat penjelasan lebih lanjut mengenai kecelakaan yang mengakibatkan kerusakan dan kerugian, juga terdapat inkonsistensi mengenai penyebab tergulingnya mobil inventaris penggugat, di awal gugatan penggugat menyatakan bahwa kecelakaan terjadi karena mobil inventaris berada di jalan aspal yang rusak kemudian berpapasan dengan kendaraan lain namun di dalam persidangan dinyatakan bahwa kecelakaan terjadi karena tergugat mengemudi dengan kecepatan yang terlalu tinggi 
2. Tim yang dibentuk oleh PT. Thailindo Bara Pratama melakukan investigasi yang mandiri dan independen kemudian hasil dari investigasi langsung dikategorikan sebagai fakta hukum

3. Penggugat sama sekali tidak menyertakan bukti telah dilakukannya upaya bipartit dan tripartit baik itu risalah penyelesaian maupun anjuran, namun hal itu dilampirkan oleh tergugat. Majelis hakIm sama sekali tidak menjadikan hal ini sebagai pertimbangan hukum dan tetap menyatakan gugatan penggugat adalah sah, hal ini bertentangan dengan Pasal 83 ayat (1) Undang-Undang Nomor 2 Tahun 2004 tentang Penyelesaian Perselisihan Hubungan Industrial

4. Alasan penggugat tidak melakukan proses pidana adalah agar tidak memberatkan terdakwa, padahal dalam kasus ini penetapan pidana sangat diperlukan untuk memperjelas terjadinya kecelakaan, seharusnya pula melibatkan pihak ketiga yang bersifat netral yaitu pihak kepolisian

5. Penggugat sama sekali tidak menuntut ganti rugi padahal penggugat menyatakan tergugat telah melakukan kesalahan berat dengan kerugian di atas $\mathrm{Rp}$ 5.000.000,00 (lima juta rupiah) dan juga telah melanggar Peraturan Perusahaan

6. Surat estimasi biaya perbaikan adalah berasal dari Senior Coordinator W/S yang diketahui manager bukan berasal dari pihak ketiga yang berkompeten seperti bengkel atau toko suku cadang kendaraan resmi

7. Ketiga saksi dari pihak penggugat tidak ada yang berada di lokasi kejadian saat kecelakaan terjadi, mereka semua hanya megetahui dan mendengar dari sumber yang tidak disebutkan

8. Ada kejanggalan mengapa tergugat tidak datang saat upaya tripartit dan tidak ada penjelasan mengenai alasan tergugat atasnya, penggugat juga terkesan sangat ingin menjatuhkan pemutusan hubungan kerja atas diri tergugat

9. Penggugat tidak melakukan pemberian surat peringatan terlebih dahulu sebelum memutuskan untuk menjatuhkan pemutusan hubungan kerja atas diri tergugat 


\section{Kesimpulan}

Peraturan perundang-undangan yang berlaku saat ini telah mengatur mengenai pemutusan hubungan kerja karena kesalahan berat pekerja/buruh yaitu melalui Undang-Undang Nomor 13 Tahun 2003 tentang Ketenagakerjaan, Undang-Undang Nomor 2 Tahun 2004 tentang Penyelesaian Perselisihan Hubungan Industrial, Putusan Mahkamah Konstitusi Republik Indonesia Nomor 12/PUU-I/2003 dam Surat Edaran Menteri Tenaga Kerja dan Transmigrasi Nomor SE.13/MEN/SJ-HKI/I/2005 yang pada intinya mengatur bahwa pemutusan hubungan kerja akibat kesalahan berat pekerja/buruh harus berdasarkan putusan pengadilan yang telah berkekuatan hukum tetap, yang berarti kewenangan tersebut bukan berada di pihak pengusaha.

Mekanisme pemutusan hubungan kerja akibat kesalahan berat pekerja/buruh menggunakan dasar hukum Undang-Undang Nomor 2 Tahun 2004 tentang Penyelesaian Perselisihan Hubungan Industrial yaitu melalui proses bipartit, tripartit dan Pengadilan Hubungan Industrial. Proses bipartit dan tripartit harus dilakukan terlebih dahulu sebelum salah satu atau kedua belah pihak mengajukan gugatan ke Pengadilan Hubungan Industrial. Dalam proses beracara di Pengadilan Hubungan Industrial berlaku hukum acara perdata khusus.

Di dalam Putusan Pengadilan Hubungan Industrial Palangkaraya Nomor 04/G/2012/PHI.PN.PL.R terdapat banyak celah hukum antara lain penggugat tidak menyertakan risalah mediasi di dalam gugatan di Pengadilan Hubungan Industrial, perbedaan pemahaman dan dasar hukum pemutusan hubungan kerja akibat kesalahan berat pekerja/buruh antara pengusaha dengan Pengadilan Hubungan Industrial Palangkaraya, tidak ada penetapan mengenai kecelakaan lalu lintas oleh pihak yang berwenang dan peraturan perusahaan yang bertentangan dengan peraturan perundangundangan.

\section{Daftar Pustaka}

Abdussalam, H. R. dan Adri Desasfuryanto. 2015. Hukum Ketenagakerjaan (Hukum Perburuhan). Jakarta : PTIK.

Ashshofa, Burhan. 2010. Metode Penelitian Hukum. Jakarta : Rineka Cipta.

Asri Wijayanti. Perlindungan Hukum Bagi Pekerja yang di PHK Karena Kesalahan Berat. Jurnal Pendidikan Hukum Dan Ketenagakerjaan UMM, 2010. 
Asyhadie, Zaeni. 2007. Hukum Kerja : Hukum Ketenagakerjaan Bidang Hubungan Kerja. Jakarta : PT. Raja Grafindo Persada.

Bambang, Joni. 2015. Hukum Ketenagakerjaan. Bandung : Pustaka Setia.

Damanik, Sehat. 2007. Hukum Acara Perburuhan. Jakarata : DSS Publishing.

Djumialdji dan Wiwoho Soejono. 1987. Perjanjian Perburuhan dan Hubungan Perburuhan Pancasila. Jakarta : Bina Aksara.

Djumialdji. 1987. Pemutusan Hubungan Kerja (Perselisihan Perburuhan Perorangan). Jakarta : Bina Aksara.

Husni, Lalu. 2015. Pengantar Hukum Ketenagakerjaan. Jakarta : Rajagrafindo Persada.

Khakim, Abdul. 2003. Pengantar Hukum Ketenagakerjaan. Bandung : PT. Citra Aditya Bakti.

Khakim, Abdul. 2014. Dasar-Dasar Hukum Ketenagakerjaan. Bandung : PT. Citra Aditya Bakti.

Muharam, Hidayat. 2006. Hukum Ketenagakerjaan Serta Pelaksanaannya di Indonesia. Bandung : PT. Citra Aditya Bakti.

Putusan Mahkamah Konstitusi Republik Indonesia Nomor 12/PUU-I/2003

Rusli, Hardijan. 2011. Hukum Ketenagakerjaan. Jakarta : Ghalia Indonesia.

Salam, Moch. Faisal. 2009. Penyelesaian Perburuhan Industrial di Indonesia. Bandung : CV. Mandar Maju.

Sastrohadiwiryo, Siswanto. 2003. Manajemen Tenaga Kerja Indonesia Pendekatan Administrasi dan Operasional. Jakarta : PT. Bumi Aksara.

Siti Aisyiah. Pengaruh Kebijakan Pemutusan Hubungan Kerja Terhadap Motivasi Kerja Dan Disiplin Kerja Pada Karyawan Tambang Batu Bara PT. Ryan Eka Pratama Samboja. E-Journal Psikologi Fisip Unmul, 2016.

Soepomo, Iman. 2003. Pengantar Hukum Perburuhan. Jakarta : Djambatan.

Soepomo, Iman. 2016. Hukum Perburuhan Bidang Hubungan Kerja. Jakarta : Djambatan.

Sri Zulhartati,.. Pengaruh Pemutusan Hubungan Kerja Terhadap Karyawan Perusahaan. Jurnal Pendidikan IPS, FKIP, Universitas Tanjungpura Pontianak, 2012.

Suhartoyo. Perlindungan Hukum Terhadap Pekerja/Buruh Penyandang Disabilitas Di Indonesia. Jurnal Masalah-Masalah Hukum, Universitas Diponegoro, 2014.

Sunyoto, Danang. 2014. Juklak PHK. Yogyakarta : Pustaka Yustisia.

Surat Edaran Menteri Tenaga Kerja dan Transmigrasi Nomor SE.13/MEN/SJ$\mathrm{HKI} / \mathrm{I} / 20$

Sutedi, Adrian. 2009. Hukum Perburuhan. Jakarta : Sinar Grafika.

Suwiryo, Broto. 2017. Hukum Ketenagakerjaan Penyelesaian Perselisihan Hubungan Industrial Berdasarkan Asas Keadilan. Yogyakarta : LaksBang PRESSindo.

Undang-Undang Nomor 13 Tahun 2003 tentang Ketenagakerjaan

Undang-Undang Nomor 2 Tahun 2004 tentang Penyelesaian Perselisihan Hubungan Industrial

Uwiyono, Aloysius, dkk., 2014. Asas-Asas Hukum Perburuhan. Jakarta : Rajawali Pers. 
Wijayanti, Asri. 2014. Hukum Ketenagakerjaan Pasca Reformasi. Jakarta : Sinar Grafika.

Wiradipradja, Saefullah. 2016. Penuntun Praktis Metode Penelitian dan Penulisan Karya Ilmiah Hukum. Bandung : Keni Media.

Zulmawan, Wawan. 2017. Panduan Praktis Pelaksanaan Hubungan Industrial. Jakarta : Permata Aksara. 